\title{
Barns tro og lek i sanden - dialog i og rundt sandkassen
}

\author{
Av Steinar Ims \\ STEINAR IMs (født 1971), prest og daglig leder, Kirkelig dialogsenter. \\ Adr:: Olaf Ryes plass 7, 0552 Oslo. E-post: steinar@kirkeligdialogsenter.no
}

\begin{abstract}
Artikkelen er et bidrag til å reflektere teologisk og religionsteologisk om spillerommet barna får $i$ utviklingen av tro og identitet. Med utgangspunkt $i$ tros- og livssynsmangfoldet $i$ barnehagene, argumenterer jeg for viktigheten av opplaring i dialog som metode for barna. Dialogen er et verktøy for å håndtere forholdet mellom det enkelte barns trostilhørighet og et konstruktivt tros- og livssynsmangfold. Dette er et nybrottsarbeid som scerlig pedagoger $i$ barnehagene må ta ansvar for. Det er dessverre ennå en stor mangel på kunnskap om og erfaring med religiøs dialog $i$ de fleste hjemmene. Temaet er også relevant for barn i skolealder.
\end{abstract}

Denne artikkelen ble opprinnelig utformet som et bidrag til IKO-kursene «Dialog på tvers» for barnehageansatte i (hovedsakelig) kristne barnehager i Osloområdet og i Bergensområdet $\mathrm{i}$ januar 2012.

Målet med artikkelen er for meg som kristen teolog og prest å bidra med noen perspektiver om hvordan vi tenker teologisk og særlig religionsteologisk om det merkbare mangfoldet som er del av barnas oppvekst i dag. Det er viktig å understreke at dette er skrevet ut fra mitt ståsted i majoritetstrossamfunnet Den norske kirke. Tanken er å bryte med noen forestillinger om hva vi legger i begrepet «tro», og å åpne opp for å utforske innholdet $\mathrm{i}$ begrepet. I forlengelsen av dette er det sider ved tros- og livssynsdialogen som samsvarer med en forståelse av trosbegrepet som nyansert og sammensatt. Mitt oppdrag som dialogprest er i denne sammenhengen å gi noen «knagger» å henge begrepet dialog på, forhåpentligvis også som et bidrag til dialog $\mathrm{i}$ barnehagene og på skolen. Hvem dette involverer og hvorfor vi skal gjøre det. Hvordan det skal gjøres vil i mindre grad bli berørt her. Et av de viktigste områdene for læring i tiden som kommer i tilknytning til barns oppvekst, er dialogisk metodikk i sin alminnelighet og i særlig grad knyttet opp til tros- og livssynsmangfoldet.

\section{RELIGIONSTEOLOGI I HVERDAGEN}

Mangfoldet av tros- og livssynsretninger er stadig mer merkbart i barnehagene og skolene. Den norske kirkes ansatte merker det økte mangfoldet også i de kirkelige handlinger, inkludert de sakramentale handlingene dåp og nattverd. Kirkelig dialogsenter, hvor jeg arbeider, arrangerer jevnlig ulike former for kurs eller samlinger hvor vi tar for oss aktuelle problemstillinger tilknyttet kirkens arbeid og trosog livssynsmangfoldet. I januar 2012 arrangerte vi et møte hvor tema var Samarbeid om gravferd - dialog $i$ møte med sorg og død, og innledere var prisvinnerne av toleranseprisen 2011, ${ }^{1}$ imam Senaid Kobilica og sokneprest Anne Marit Tronvik. De fortalte om sitt samarbeid i forbindelse med Bano Abobakar Rashids gravferd 29. juli 2011. Rashid var en av de 69 som ble drept på Utøya syv dager tidligere.

1 Toleranseprisen utdeles årlig av Stortingets presselosje (http://presselosjen.no/toleranseprisen/). 
Bildet av de to som leder an det muslimsk-kristne gravfølget frem mot graven, gikk verden rundt som en illustrasjon på hvordan ulike trosretninger kan samarbeide på tvers i møte med menneskelige kriser og katastrofer.

Det er på bakgrunn av kriser som denne, men også i forbindelse med fest, høytid og hverdag at vår tro eller overbevisning utfolder seg og formes. Vi møter alt dette gjennom vår praksis, måten vi håndterer de situasjoner som oppstår. Til forskjell fra det forholdsvis homogene Norge for 100 år siden er vi i dag i en situasjon hvor avdøde i begravelser kan ha to- eller flerreligiøs bakgrunn og familie. Denne artikkelen ville ikke blitt skrevet hvis det ikke var for at også barn med ikke-kristen bakgrunn går i kristne barnehager, og hvis ikke samfunnet hadde endret seg i retning av et stadig større mangfold av kulturer, språk og tros- og livssynsretninger. Dette er et faktum. Det betyr også at vi innenfor teologien, læren om Gud, må forholde oss til at dette er en del av skaperverket, og en del av den verden som er gitt oss fra Gud.

En kristen vei inn i dialogen er derfor først og fremst gjennom å ta våre liv i større og mindre fellesskap på alvor; i familien, blant venner, på arbeid, på skole, i lokalsamfunn og så videre. ${ }^{2}$

\section{LEK I SANDKASSEN}

Inspirasjon for overskriften min er artikkelen «Lesning i sandkassen» som professor i Det gamle testamentet, Martin Hauge, skrev til et etterutdanningskurs for prester (Hauge, 1994). Hauges poeng med overskriften er å skape et fortolkningsrom for «lek» med bibeltekstene der tanker, innfall og ideer kan spilles fritt ut. Sandkassen er et utprøvningsverksted, et sted der alt er mulig. Rommet begrenses alltid før eller siden av kassen og virkeligheten «utenfor». Beskrivelsen er selvfølgelig enda mer dekkende når det gjelder barna selv, og i dette tilfellet når det gjelder deres trosliv. Sandkassen er et bilde på hvordan barnas verden er full av ubegrensede muligheter i leken med sand, tildelte leker og redskaper og rammer for oppførsel. Den er preget av det sanselige, det jeg tenker er veien inn i barnas religiøse verden og trosforestillinger. Alt dette er med på å gi mening og klare holdepunkter. Noen ganger gjør erfaringer med verden utenfor sandkassen det nødvendig å flytte rammene for vår verden eller til og med å rive ned hele kassen. Jeg har i mitt arbeid med dialog møtt mye usikkerhet og frykt i forholdet til det mangfoldige og mer livssynsåpne samfunnet: frykten for at mangfoldet vil endre vår egen tro og trosuttrykk, og frykten for det fremmede i form av trusselbilder (særlig i møte med muslimer) der kirken holder på å bli en truet «minioritet» i lokalsamfunnet. Kunnskap er en nøkkel i møte med frykt, og jeg tenker det inkluderer en større kunnskap om og utforskning av våre egne og barnas trosforestillinger. Jeg har valgt sandkassen som en positiv metafor som kanskje kan åpne opp for denne utforskningen.

\section{SANDEN}

En venn av meg studerte teologi og arbeidet $i$ en barnehage på samme tid. Et av barna stilte seg av og til opp midt på gulvet, gjerne på en liten kasse, og talte med myndig og vennlig stemme til de andre barna. Tema var om det meste som måtte falle ham inn, gjerne bibelhistorier $i$ lett blanding med fortellinger fra Byggmester Bob og Thomastoget. Ingen av de (forholdsvis kirkefremmede) barnehageansatte skjønte helt hva som foregikk. Guttens foreldre var prester, og min venn skjønte umiddelbart at gutten stod og prekte, inspirert av jevnlige besøk $i$ kirken og foreldrenes prekener.

Vi vet at barns lek er en del av deres dannelse, at lek også er utforskning av livet. I en slik lek

2 Den norske kirke har utgitt flere ressurser om hvordan vi møter det flerreligiøse samfunnet, se f.eks. Hovedprinsipper for Mellomkirkelig råds interreligiøse engasjement, 2008. 
er ikke alltid tilhørerne så viktige, det viktigste kan være bearbeiding av inntrykk som gjøres gjennom rollespill eller i dialoger vi har med oss selv. Mary Watkins (Watkins, 1986) har i boken Invisible Guests - The Development of Imaginal Dialogues, utforsket disse «indre dialogene». Selv om de endrer karakter fra barndom til ungdom og voksenliv, er de likevel viktige for vår mentale helse og vår evne til å sortere inntrykk og opplevelser. Martin Buber hevder, litt forenklet, at det finnes tre former for dialog slik vi finner det i Det gamle testamentet: dialog med våre naboer, dialog med Gud og dialog med oss selv (Buber, 1992). For barn er det akseptert å ha dialog med seg selv i form av usynlige venner eller oppdiktede samtaler. For oss andre vil slike dialoger ofte ende opp i diagnostisering, om vi ikke da definerer samtalene som bønn. Hauge peker på at vi også som voksne trenger et slikt rom for indre dialoger, i hans tilfelle som ekseget (bibelfortolker) i møte med bibeltekster. For barna er sanden i sandkassen stedet for å utforske, skape, bearbeide og så igjen prøve ut uttrykk i samtale med seg selv. Det er et trygt sted hvor, slik Hauge sier det, alt kan skje. Og vi oppmuntrer stort sett alt til å skje der. Det er barnas frirom, hvor det er lov å grise, bygge, rive ned, smake (på sanden), dominere, være sammen og så videre. Et sted hvor det i all hovedsak er barna selv som definerer innholdet $\mathrm{i}$ leken.

\section{LEKENE OG REDSKAPENE}

$P a ̊$ vei hjem $i$ bilen fra fotballkamp snakker min 7-årige sønn og hans lagkamerat Mahammado sammen $i$ baksetet. Vi var midt $i$ den kristne fastetiden, og min sønn forteller ganske stolt at han Nintendofaster. Mahammado er litt forbauset: "Faster dere kristne da?". "Ja - men ikke sånn som dere gjør - selv om vi kan gjøre det også. Vi spiser ikke kjøtt og har ikke godteri. Og så har jeg valgt å la vere å spille Nintendo". "Kult», svarer Mahammado, «Jeg bare prøver å faste litt noen dager under ramadan, jeg, men jeg begynner ikke ordentlig for jeg blir 14 år. Hadji [storebror] skal begynne neste år... Har du spilt det siste spillet på Nintendoen med ...?”.

Leken i sanden er preget av lekene som vi gir barna. De tar med seg noe inn i leken som representerer verden rundt dem: biler, tog, dukker, byggeklosser, spader og bøtter. Ting som kan forme, og ting som kan fylle den formede verden. Vi vet veldig godt at barnas verden er tydelig definert av de redskapene de blir tildelt fra blant annet foreldre, barnehagen, kultur og trostradisjon, kjønn og søsken. Sandkassens verden er bare tilsynelatende et sted med uendelige muligheter. Mulighetene begrenses, også i fantasien, av hva vi bringer med oss.

\section{SANDKASSEN}

En venn av meg fortalte om en samtale mellom hennes sønn og noen av hans venner. De var i tidlig skolealder og snakket om religiøs tilhørighet: "Mohammed er jo muslim", sa en av dem, "og du, Mattias, er jøde". "Jeg er katolikk", sa Vemund. "Men hva er du da, Benjamin?", sa en annen. "Jeg vet ikke", svarte Benjamin. "Da er du kristen," svarte min venns sønn.

Sanden og lekene befinner seg helt klart innenfor en ramme. Det er en helt klart avgrenset verden, og det er en verden utenfor hvor vi helst ikke vil at all sanden skal bli dradd utover, eller forbi ytterdøren og inn i gangen. For barna er kanskje grensene noe utflytende, men de er klare og avgrensede for oss voksne. Det gjør vi barna tidlig oppmerksomme på. Både empati, disiplin og rammer må læres. Og religiøs identitet: "Sånn gjør vi det» eller «sånn gjør vi det ikke». Og ikke minst som negative speilinger av de andre: «Kanskje de andre gjør det sånn, men det gjør ihvertfall ikke vi»! Grenseoppgangene er en livslang læring, som vi møter på i alle sammenhenger gjennom hele livet. 


\section{UTENFOR SANDKASSEN}

En konfirmantgruppe i Domkirken i Oslo hadde som avslutningen på et omfattende opplegg knyttet til religionsdialog vert på tur til New York. Der overleverte de bl.a. et kunstverk de hadde vert med å utforme til en moské like ved minnesenteret for 11. september 2001. Møtet med mennesker i New York med forskjellig tro, og kanskje scerlig med muslimer som hadde opplevd mistenkeliggjøring og fordommer i etterkant av terroraksjonene 11. september, gjorde sterkt inntrykk på konfirmantgruppen. Som en oppsummering av turen og hva de hadde lart om å leve som kristne, sa en av konfirmantene: "Å vere kristen ... det er å leve i kjerlighet ... og i dialog."

Hva befinner seg for barna utenfor sandkassen? Er det livet i kjærligheten og i dialogen? Eller en verden hvor tro er avgrenset av våre dogmer og læresetninger? Lar dette seg uten videre overføre til den religiøse verden? Vil en vektlegging av sanden og lekene i motsetning til kassen og verden utenfor medføre en fare for å ende opp i synkretisme? Hva skjer når ulike tradisjoner møtes og blir en del av barnas oppvekst?

Vi har to fødselsberetninger $\mathrm{i}$ vår kristne tradisjon: i Matteus- og i Lukasevangeliet. Til vanlig forbinder vi Jesu fødsel med Lukasberetningen: «Det skjedde i de dager ...» samt fortellingen om vismennene fra Matteus. Barna kan i dag få kjennskap til tre fødselsberetninger. I tillegg til evangelietekstene kommer den vakre historien i Koranens sure 19, 22-34. Bildene av gjetere, dyr og engleskarer fra Lukasevangeliet er allerede godt blandet med bilder av tre vise menn med eksotiske navn fra Matteusevangeliet og senere historier. Nå utfylles fortellingene med bilder av palmer, vannkilder og et snakkende Jesusbarn fra Koranen, og vice versa for de muslimske barna. Gjør dette dem til mer synkretistiske kristne og muslimer av den grunn? Er det et problem med tanke på religiøs identitet, eller vil de fort nok finne ut av det etter hvert som de vokser til og blir eldre? Nå berører vi to områder som er sentrale og krevende i forholdet til barn og tro. Det teologiske: Hva er rett lære, og i hvor stor grad er vi selv med på å forme vår egen tro? Det pedagogiske: Hvordan lærer barna om egen trosidentitet og om trosmangfoldet på riktig måte?

Jeg har valgt å ta utgangspunkt i barnas sandkasse og veien ut av sandkassen, det er en sentrifugal bevegelse utover fra sandkassen. Med teologi og læring har vi beveget oss ut av sandkassen og inn i de voksnes verden, den som domineres av foreldre, foresatte og ansatte i barnehagen, på skolen eller i trossamfunnene barna tilhører.

\section{DE VOKSNES VERDEN}

Da jeg var barn, talte jeg som et barn, tenkte jeg som et barn, forsto jeg som et barn. Men da jeg ble voksen, la jeg av det barnslige (1. Kor. 13,11).

Der ulike deler av barnas verden glir over i hverandre, er det for oss tydeligere skiller og klarere avgrensninger, ihvertfall tilsynelatende. Vi prøver veldig hardt å systematisere vår utforskning av identitet og tilhørighet. Men vi møter stadig de aktuelle religionsteologiske spørsmål i et mangfoldig samfunn: Hvorfor er det så mange religioner? Hvis Gud er én, skulle det ikke vært én religion? Hvordan skal de religiøse tradisjoner forholde seg til hverandre, og hvordan skal min religiøse tradisjon forholde seg til andre? Kan jeg lære mer fra dem enn jeg kan lære fra min egen tradisjon? (Knitter, 2002, ss. 1-4). Som nevnt innledningsvis møter vi disse spørsmålene i dag også i forbindelse med de kirkelige handlinger: Når en person med flerreligiøs bakgrunn skal begraves. Når halvsøster til dåpsbarnet er buddhist, men gjerne vil være fadder, eller når brud og brudgom tilhører to ulike religiøse tradisjoner.

De religionsteologiske spørsmålene er kanskje 
ikke spørsmål vi umiddelbart ønsker å stille til barnehagebarn, til det sliter vi for mye med dem selv. Men hvorfor ikke? På litt lengre sikt er det slike spørsmål barn i et tros- og livssynsmangfold skal forholde seg til. Metoder som f.eks. filosofiske samtaler har vist at dette er spørsmål som barn og ungdom er fullt i stand til å besvare, bare vi vet å stille spørsmålene på riktig måte.

Jesus var selv en jøde. I kristen tradisjon ligger Jesu liv forut for de dogmatiske læresetningene i kristendommen. Fra hva vi kan lese ut av fortellingene om Jesus, ser det ut til at han var særlig opptatt av tre ting: å forkynne Guds rike, å illustrere dette gjennom undere og fortellinger, og å invitere marginaliserte og utstøtte mennesker inn i måltidsfellesskap (Moxnes, 2006, ss. 17-22). Hvilken betydning dette har for kristne i dag, diskuteres i det vide og brede, men det er helt klart at det berører mange og ulike sider ved kristnes liv og praksis. La oss gjøre et forsøk på å systematisere de ulike sidene ved religiøst liv. Religionsviteren Ninian Smart prøver å hjelpe oss med det. Han deler de religiøse uttrykk inn i ulike dimensjoner (Smart, 1998, ss. 1-25):

- Den filosofiske og dogmatiske dimensjon dogmer, systemer.

- Den narrative eller mytiske dimensjon tekster, fortellinger.

- Den etiske eller lovmessige dimensjon regler for adferd.

- Den rituelle dimensjon - seremonier og ritualer.

- Den erfaringsmessige eller emosjonelle dimensjon - vår følelse for tro.

- Den sosiale eller institusjonelle dimensjon menigheter, trosfellesskap.

- Den materielle dimensjon - objekter, steder, symbolgjenstander.
I følge Smart vil ulike trosretninger ha ulik vektlegging av disse syv områdene. De fleste vil ha elementer av dem alle i sin tradisjon. Innenfor samme tradisjon vil det naturligvis være forskjeller fra individ til individ. Hver enkelt av oss vil tillegge de forskjellige deler av vår tro og trospraksis større eller mindre verdi, og dette vil også endre seg etter behov og livssituasjon. Smarts kategorier viser også at det er glidende overganger mellom det vi tenker på som kulturell arv og det vi tenker på som religiøs praksis. For barnehagebarn vil disse skillene være enda mer diffuse. Jeg tror det er helheten i fortellerstunden, med gode historier, deilige boller, trygghet og fellesskap, som kvalitativt gir stunden verdi for barna. Hvorvidt fortellingen er en historie om apeguden Hanuman, Jesus eller Buddha vil bety noe i forhold til gjenkjennelse eller ikke. Men kanskje det stopper der? Er historien både spennende og levende fortalt, vil den bli godt mottatt uansett. Betyr det noe med tanke på religiøs dannelse? På samme måte kan vi spørre oss i hvor stor grad markering av høytider, deltagelse på gudstjenester eller besøk i kirken og andre gudshus eller forsamlingslokaler vil prege barna religiøst? Er det greit at vi deler våre ulike tros- og livssynstilhørigheter med barna? Hvordan skal pedagogene møte disse utfordringene? Hvordan løfter de frem mangfold og religiøs identitet som er naturlig inn i barnas verden og som samtidig ivaretar religiøs tilhørighet? Smarts inndeling kan gi oss et redskap til å se muligheter for å åpne opp deler av det religiøse landskapet for barn uten at vi relativiserer, forkynner eller gjør barna til representanter for sine respektive trostradisjoner. ${ }^{3}$

\section{HVA ER DIALOG?}

Igjen kan det være lurt å ta utgangspunkt i de voksnes verden, og å foreta en liten sorteringsjobb. Oddbjørn Leirvik skiller mellom to hovedtyper av dialog: Den nødvendige og den spirituelle

3 For mer utfyllende diskusjon rundt disse problemstillingene, se f.eks. Gjervan, 2006, og Sødal, 2000. 
(Leirvik, 2007, ss. 57-67). Men for å synliggjøre kompleksiteten i de ulike formene for dialog, kan vi foreta en ytterligere inndeling. På samme måte som Ninian Smart prøver å finne noen mønstre vi kan operere etter i vårt trosliv, har Kajsa Ahlstand prøvd det samme for ulike former for dialog (Ahlstrand, 2005, ss. 61-70):

- Det levde livets religionsdialog

Der mennesker kommer sammen i hverdagslivet. Religion er ikke utgangspunkt for møtet. Spørsmål som kommer opp, er eksempelvis «kan vi reise på klassetur under ramadan?» og «hvordan tilrettelegger vi i barnehagen, idrettslaget eller i skolehverdagen for mat ut ifra ulike religiøse forskrifter?»

- Dialog om sosiale spørsmål

En tar utgangspunkt i felles sosiale spørsmål som vold, rus, helse, skole og sosial aktivisme.

- Bønnens dialog

Felles bønn og/eller meditasjon. Deltagelse i hverandres praksis.

- Intellektuell dialog

Den best dokumenterte formen for dialog. Krever en ganske høy teologisk selvtillit, men er ingen disiplin bare for spesialister. Kan eksistere innenfor alle de andre formene for dialog.

- Kulturlivets dialog

Mystikk og estetikk. Møter mellom for eksempel musikere fra ulike tradisjoner (som CD-en Dialogues med Sondre Bratland og Javed Bashir) eller innenfor andre kunstuttrykk. Utøverne kan ha ulik nærhet til de religiøse tradisjonene, men er ikke likegyldig til dem.

- Å arbeide sammen for tradisjonelle verdier

Eksempelvis felles arbeid mot homofile rettigheter (jamfør muslimer og kristne sammen mot ny ekteskapslov i demonstrasjon 12. april 2009). Det kan også være kamp mot fri abort, mot alkohol og mot seksualundervisning i skolen.

- A arbeide sammen for forandring

For eksempel kvinner som arbeider sammen mot fundamentalisme og patriarkalske strukturer. Det kan også være engasjement for miljøsaken, for felles innsats i utsatte deler av verden (naturkatastrofer, alvorlige ulykker og så videre), for fred i lokalsamfunn eller i forbindelse med konflikter i ulike deler av verden. Tanken er at gode krefter må søke sammen.

Dialogen er altså ikke forbeholdt de alvorlige, litt eldre mannlige religiøse ledere i sine eksistensielle samtaler. Det er i forlengelsen av det heller ikke forbeholdt de som er «trygge i troen». For meg blir det tydelig med Ahlstrands systematisering hvor komplekse og mangfoldige våre religiøse liv er, og hvor mange felt vi kan gå i dialog med våre naboer på, om de er religiøst annerledes eller ikke. Der Smart sier noe spesifikt om hva vi fyller vår religiøse verden med, sier Ahlstrands inndeling noe om krysningspunkter i vår hverdag som bryter opp forestillingen av vår religiøse sandkasse som noe helt annet enn den andres religiøse sandkasse. Vi deler noe på tvers av tros- og livssynstilhørigheten vår. Det gjelder også for barna, og særlig i forholdet mellom barna og deres foreldre/foresatte og barnehagenes ansatte og pedagogiske arbeid. Alle Ahlstrands dialogområder kan være relevante for barnehagen (og skolene), med unntak av arbeid for tradisjonelle verdier. Jeg inkluderer her både bønnens dialog forstått som stillhetsarbeid for barn $^{4}$ og den intellektuelle dialogen, slik vi finner den i blant annet filosofiske og eksistensielle samtaler med barna som aktører. ${ }^{5}$

Bildet av sandkassen blir nå kanskje snudd på hodet, og vi er i gang med en sentripetal bevegelse

4 Se f.eks. opplegg for sjokolademeditasjon for barn hos Ims, 2010.

5 Se f.eks. Hull, 1991, og Helskog. 
inn igjen i sandkassen fra vårt ståsted som voksne i letingen etter steder hvor vi kan dele med hverandre og barna. Det som er viktig på denne veien, er å forstå hva som ligger i all dialog og i en dialogisk væremåte. Vi må ta med oss noen redskaper tilbake til sandkassen.

\section{DIALOG SOM REDSKAP}

$\ll$ Dialog skiller seg fra forhandlingen ved at man ikke trenger å bli enig. Den skiller seg fra diskusjonen ved å ikke bare snakke saklig, men også personlig. Den skiller seg fra debatten ved at målet ikke er å vinne, men å ha mot og tid til å forstå den andre» (Hareide, 2007). Dag Hareides definisjon er en nødvendig påminnelse i vår voksenverden. Den hjelper oss å forstå spillereglene for hvordan vår samtale med hverandre utarter seg. De som arbeider med barn, vil kunne gjenkjenne deler av dialogens kjennetegn som en nødvendig del av det å arbeide med barn: ikke alltid bare saklig, men også personlig, ha tid til å forstå hverandre og så videre. Det kanskje viktigste bidraget til en erkjennelse av hva dialog bidrar med i mellommenneskelige relasjoner, er forholdet til makt. Det gjelder på alle nivåer av samtalen om barnas religiøse oppvekst og oppdragelse: forholdet til barna selv og deres (tros-) uttrykk, forholdet mellom de voksne og barna, forholdet mellom de ulike voksne aktørene (ansatte, foreldre og foresatte) forholdet til lovverk og forskrifter og forholdet mellom de ulike religiøse tradisjoner og hvordan vi formidler dem til barna. Et kjennetegn ved de ulike dialogdefinisjoner er behovet for en tilnærmet likeverdighet mellom partene i dialogen, og viljen til å endre seg gjennom møtet med den andre: «Dialog er et møte ansikt til ansikt mellom likeverdige parter uten skjulte hensikter.Jeg går inn $i$ en dialog, ikke for å forandre den andre, men for å ta del i den gjensidige forandring som kan skje gjennom et møte.» (Grung, 2005, s. 88. Se også Svare, 2006, s. 7, og Isaacs, 1999, s. 19). Idealet som Grung skisserer, lar seg vanskelig oppfylle i arbeid med barn, men definisjonen, i likhet med Hareides, er en viktig påminnelse om intensjonene bak den dialogiske tenkning og metode.

\section{BARN SOM DIALOGAKTØRER}

Ingen blir naturlige dialogaktører selv om de er vokst opp i et flerreligiøst samfunn og med en selvfølgelighet i forholdet til det flerreligiøse. Barn trenger opplæring i sameksistens og dialogisk væremåte. Her tror jeg dessverre mange foreldre og foresatte ikke har gode nok kunnskaper eller erfaringer med interreligiøs dialog til å kunne bidra til opplæringen av barna. Men opplæring hjemmefra i normal høflighet og god samtaleskikk er et godt utgangspunkt for videre læring i dialog. Veien videre kan for eksempel gå via de filosofiske og eksistensielle samtaleformene som også er utarbeidet for barn. Det er derimot ikke tvil om at dette feltet, særlig når vi kommer inn på de religiøse uttrykkene, fremdeles er nybrottsarbeid i norsk sammenheng. Dette er et forholdsvis nytt felt $i$ vårt samfunn, og det trengs pedagoger og andre ansatte som tør å prøve ut ulike former for dialog med barna og deres foreldre. Et godt sted å begynne kan kanskje være i kollegafellesskapet?

En bevissthet om egen religiøs tradisjon og tilknytning kommer tidsnok i barnas oppvekst. Faren for at barn vokser opp som synkretister, med bakgrunn i tre og ikke en eller to fødselsberetninger, er ikke stor. Faren er større for at religiøs forskningstrang ikke får spilles ut, verken hos barn eller voksne, i frykt for å tråkke lovverk eller foresatte på tærne eller i frykt for identitetsløse generasjoner med synkretistiske tendenser. La oss igjen bevege oss inn i sandkassen og fortellingene og det sanselige i leken.

Pedagoger i barnehagene vet at det finnes noen fortellinger om Jesus som fungerer bedre enn andre for barn. På samme måte finnes ulike spørsmål vi følger opp fortellingene med. I min egen kirke er det en lang tradisjon for å stille ledende spørsmål: «Hva var det Jesus egentlig 
mente?» Skal vi som formidlere frem til noe allmennmenneskelig, eller skal vi finne frem til de riktige religiøse svarene? Tør vi i stedet å la barna komme i berøring med grunnleggende spørsmål uten å legge svarene i munnen deres?

De fire historiene innledningsvis, om barns og ungdommers forståelse og tolkning av religiøs identitet og religiøs praksis, er hentet ut av en større sammenheng tillagt særlig vekt av en voksen gjenforteller. For barna sin del tviler jeg på at den religiøse samtalen hadde kvalitativt større verdi enn andre deler av samtalene. Jeg tror at min sønn og Mahammados samtale om de nyeste Nintendospillene var like viktig som samtalen om faste. Barnas agenda er ikke nødvendigvis den samme som vår. I min verden er den religiøse praksisen viktigere enn Nintendospill i dannelsen av gode mennesker, både kristne og muslimer i dette tilfellet. Men jeg kan ikke utelukke at fasten på en eller annen måte blir preget av tanken på Nintendospill (eller fravær av slike spill) for både min sønn og Mahammado i årene som kommer. Det tror jeg kan være av det gode. De religiøse uttrykk og den religiøse dannelse av barna må balansere mellom alminneliggjøring og kontekstualisering. De religiøse uttrykk må ikke stenges inne i egne, private rom. Vi risikerer noe ved å tenke slik, men vi risikerer mer ved å la være å vise hverandre hva som betyr noe for oss.

\section{LEKEN I SANDKASSEN SOM PROBLE- MATISK METAFOR}

Jeg tilhører både en profesjon (som teolog og prest) og en tradisjon hvor problematisering, utforskning og undring over religiøs tilhørighet er en naturlig del av min tenkning om tro. For andre konfesjoner og religiøse tradisjoner vil en slik tale om troen som utforskning og lek i sandkassen i beste fall fremstå som fullstendig uforståelig. Vi utforsker ikke tro, vi tror på og praktiserer det som er gitt oss!
For andre grupper igjen er trosliv eller overbevisning et tema som kanskje er av mindre interesse. Nesten $10 \%$ av den norske befolkning tilhører ikke noe tros- eller livssynssamfunn i det hele tatt. Men også blant dem som tilhører et slikt samfunn, er det mange som ikke ønsker å bli synliggjort som «representanter» for en trosretning. De vil heller ikke at barna skal tillegges en representativ rolle tilknyttet en religiøs tradisjon. Jeg tror det er god grunn til å tenke på denne måten. Men bare til et visst punkt. Mine forestillinger er ikke riktigere enn andres, men jeg tror like fullt det er nødvendig å utfordre hverandre på forholdet til tro og identitet.

Den mye omtalte NOU 2013: 1, Det livssynsåpne samfunn. En helhetlig tros- og livssynspolitikk (Stålsettutvalget), introduserer åtte grunnleggende prinsipper for en helhetlig tros- og livssynspolitikk. Det siste prinsippet sier at: «Alle bør akseptere å bli eksponert for andres tros- og livssynspraksis i det offentlige rom» (NOU 2013: 1, ss. 7-8). I tråd med føringene fra Det livssynsåpne samfunn er det altså ikke snakk om å tillegge noen roller som religiøse aktører, men å tåle å bli eksponert for religiøse uttrykk. Det innebærer å myndiggjøre barna i møte med et flerreligiøst samfunn de allerede er en del av. Leken med religiøse forestillinger og bilder er ikke bare en lek, men en vei mot å håndtere egen tro og identitet i samspill med andres. Dette kommer til å bli stadig mer aktuelt over hele landet som nybrottsarbeid i de forskjellige lokale kontekster.

I barnehagen er det pedagogenes rolle å formidle disse komponentene i barnas liv. Først med skolealder, og særlig i ungdomsalderen, kommer skillene for alvor inn. Da er barna ikke lengre intuitive aktører i et mangfoldig samfunn. Barnehagealderen er den tiden som gir oss mulighet til å språkliggjøre og alminneliggjøre religiøsitet. Dette er det pedagogene som må insistere på og sammen med foreldrene stå ansvarlige for. 
HVORFOR DIALOG?

På en dialogkonferanse i Drammen skulle vi finne våre begrunnelser for å gå i dialog. En dame sa det ganske enkelt: «Her bor vi og her bor vi sammen!»

For henne var dette grunn nok, og det medførte også at hun gikk aktivt inn i dialog for å skape et godt lokalsamfunn, for å forstå og leve sammen med andre. Det betyr også at vi må gjøre barna i stand til å snakke om tro, eller «fravær» av tro, med hverandre. Religionsdialog er ikke bare en retning utover, det er også en påminnelse om hvor vi selv står og en måte å bli kjent med vår egen trostradisjon på. I dag er det mange barn som i liten grad kjenner sine religiøse historier og heller ikke smaken, fornemmelsen og luktene som knytter seg til religiøs identitet. Jeg har i mitt arbeid som dialogprest utfordret både voksne og ungdommer i menighetene i Den norske kirke om hvilken del av deres trosdimensjon de føler seg mest hjemme i. I en forenkling av Ninian Smarts ulike dimensjoner har jeg spurt om de identifiserer seg mest med: klare svar på trosspørsmål, trygghet og følelse av fellesskap, praksis og spirituell utvikling eller kulturell tilhørighet. Svarene og begrunnelsene er svært interessante og skiller seg ofte fra parallellspørsmålet om hva de ser på som mest dominerende ved den kristne tradisjon i Norge, om det er: dogmer og orden, gjenkjennelse gjennom tekster og fortellinger, moralsk rettledning og spirituell utvikling eller sosialt fellesskap og tilhørighet. Det er påfallende ofte ingen korrelasjon mellom hva de tenker om tradisjonen eller kirken, og hva de tenker er viktig for dem selv. Få har reflektert rundt disse spørsmålene, og enda færre har reflektert sammen med andre om dem. Eksempelet er hentet fra arbeid innenfor ett kirkesamfunn. Jeg tror bestemt at vi har en oppgave innenfor Den norske kirke i å utfordre medlemmer på å gjøre seg slike refleksjoner. Noe av veien til en større grad av refleksjon går gjennom å ta sjansen på å «leke» med våre egne trosforestillinger. Risikere å finne ut at det ikke allid er samsvar mellom hva vi forestiller oss er viktig i hodet og hva vi kjenner er viktig i hele kroppen. For så å vende blikket utover med en nysgjerrighet på hva andre måtte erfare $\mathrm{i}$ sine trosliv og -praksiser.

Jeg kan bare snakke teologisk og religionsteologisk på vegne av min egen kristne tro og tradisjon. Jeg skal være svært forsiktig med å gi utfordringer som medlem og representant for et svært dominerende majoritetssamfunn med nesten $80 \%$ av den norske befolkning som medlemmer. Men utfordringen kommer ikke fra enkeltpersoner eller trossamfunn. Den kommer fra mangfoldssamfunnet som våre barn vokser opp i. Vi har et felles ansvar for å legge til rette for at barna kan bli myndige tros- og livssynsaktører med evne til å orientere seg i et rikt, komplekst og flerreligiøst samfunn. Mye arbeid er allerede gjort for å etablere dialogrelasjoner mellom de ulike tros- og livssynssamfunnene. Mye står ennå ugjort, særlig i tilknytning til «grasrotdialoger» i lokalsamfunnene og opplæring og arbeid med dialog for barn og unge. For pedagogene i barnehagene er både formidling av tro og opplæring i dialog et stort og viktig ansvar. Skolen har det samme ansvaret og har større utfordringer i forhold til lovverket med å ta fatt $\mathrm{i}$ disse dimensjonene ved barnas liv. Arbeid med å synliggjøre barnas trosuttrykk i både barnehage og skole og bruke dialog som metodisk tilnærming, er et krevende nybrottsarbeid. Kanskje mest fordi det medfører et dypdykk i vår egen tro og et arbeid med å utfordre våre trosgrenser. 
LITTERATUR

Ahlstrand, Kajsa. 2005. Vägar: en öppen religionsdialog, Stockholm: Verbum.

Buber, Martin. [1923] 1992. Jeg og du, Oslo: J.W. Cappelens Forlag AS. Originaltittel: «Ich und $\mathrm{Du} \gg$.

Det livsynsåpne samfunn. En helhetlig tros- og livssynspolitikk, 2013. NOU 2013: 1. Oslo: Departementets servicesenter, Informasjonsavdelingen.

Gjervan, Marit; Andersen, Camilla Eline og Bleka, Målfrid. 2006. Se mangfold! Perspektiver på flerkulturelt arbeid $i$ barnehagen, Oslo: J.W. Cappelens Forlag AS

Grung, Anne Hege. 2005. «Begrepet dialog i Emmaus - noen refleksjoner om bruken av begrepet på grunnlag av erfaringer i et flerreligiøst landskap» (ss 87-94), i Kirke og Kultur nr. 1.

Hareide, Dag. 2007. «Dialog som den smale sti», Aftenposten 24.01.07.

Hauge, Martin Ravndal. 1994. «Lesning i sandkassen» (ss. 63-67), i Hellemo, Geir og Riedl, Nils Jøran (red.); Prekenen - et kunsthåndverk? Etterutdanningskurs 1993, Oslo: Det teologiske fakultet \& Det praktiskteologiske seminar.

Helskog, Guro Hansen. Filosofiske samtaler, OM-heftene: Veiledning til trosopplæreren. Tilgjengelig: http://verktøykassa.no/doc// Om\%20filosofiske\%20samtaler.pdf [5. februar 2014]
Hovedprinsipper for Mellomkirkelig råds interreligiøse engasjement. 2008. http:// www.kirken.no// ? event=downloadFile\&fa $\mathrm{mID}=37140$ [5. februar 2014].

Hull, John M. 1991. God-talk with Young Children. Notes for Parents and Teachers, Birmingham: University of Birmingham School of Education and the Christian Education Movement.

Ims, Rita Knutsen og Ims, Steinar. 2010. «Sjokolademeditasjon» (ss. 29-35), i Religion og Livssyn, tidsskrift for Religionslærerforening i Norge, nr. 3.

Isaacs, William. 1999. Dialogue and the Art of Thinking Together, New York: Doubleday.

Knitter, Paul. 2002. Introducing Theologies of Religions, Maryknoll, New York: Orbis Books.

Leirvik, Oddbjørn. 2007. Religionspluralisme. Mangfald, konflikt og dialog $i$ Norge, Oslo: Pax Forlag A/S.

Moxnes, Halvor. 2006. Hva er kristendom, Oslo: Universitetsforlaget.

Smart, Ninian. 1998. Dimensions of the Sacred: An Anatomy of the World's Beliefs, Berkeley, CA: University of California Press.

Svare, Helge. 2006. Den gode samtalen. Kunsten å skape dialog, Oslo: Pax Forlag A/S.

Sødal, Helje Kringlebotn. 2000. Barn med ulik tro. Møte med livssynsmangfoldet $i$ skole og barnehage, Kristiansand: Høyskoleforlaget AS.

Watkins, Mary. 1986. Invisible Guests. The Development of Imaginal Dialogues, Hillsdale, New Jersey: Analytic Press. 